\title{
Effect of drought and heat stresses on photosynthesis, pigments, and xanthophyll cycle in alfalfa (Medicago sativa $\mathrm{L}$.)
}

\author{
C. XU ${ }^{*, * * \dagger}$, C.G. HE ${ }^{*}, \dagger$ Y.J. WANG ${ }^{*}$, Y.F. BI ${ }^{*,+}$, and H. JIANG ${ }^{*+}$ \\ College of Animal Sciences and Technology, Yunnan Agricultural University, Kunming, Yunnan, China* \\ Kunming Agricultural Radio and Television School, Kunming, Yunnan, China ${ }^{* *}$
}

\begin{abstract}
Climate changes severely influence photosynthetic activity of plants. Studies on the combined effect of drought and heat stress on photosynthesis, pigments, and xanthophyll cycle particularly in alfalfa (Medicago sativa L.) are limited. Thus, this study investigated the combined effects of drought and heat stress in two alfalfa varieties ('Deqin' and 'Algonguin'). Results revealed that the values of the net photosynthetic rate demonstrated a significantly decreasing tendency under stresses. The effect of stresses on ribulose 1,5-bisphosphate carboxylase activity in both varieties showed a trend of first declining and then rising. Meanwhile, phosphoenolpyruvate carboxylase activity showed an increasing tendency. The intensification of stresses led to reduced photochemical efficiency and increased capability of thermal dissipation. A linear correlation was found between nonphotochemical quenching and xanthophyll cycle components. Thus, the change in carotenoids demonstrated an important role in photoprotection, the xanthophyll cycle was the main way of dissipation of excess energy under stress conditions in alfalfa.
\end{abstract}

Keywords: abiotic stress; global warming; photosynthetic parameters; thermal dissipation.

\section{Introduction}

Climate change is projected to reduce renewable surface water and groundwater resources in most dry subtropical regions. The globally averaged combined land and ocean surface temperature data show a warming of $0.85^{\circ} \mathrm{C}$ from 1880 to 2012. The Intergovernmental Panel on Climate Change asserts that global air temperatures are expected to increase by an average of $2-4^{\circ} \mathrm{C}$ by the end of the century, and this increase will probably be accompanied by changes in precipitation (IPCC 2014). Simultaneously, global warming severely influences agricultural development and ecological balance. Water shortage has also become an urgent problem. Hence, drought and temperature increase have become major global problems that seriously affect the growth and productivity of plants. The two abiotic stresses usually occur simultaneously, especially in semiarid or drought-stricken areas (Rizhsky et al. 2002). Plants adapt to stress by regulating photosynthesis, physiological and biochemical traits or some special mechanisms. Photosynthesis is one of the vital processes sensitive to water deficit and high temperature. Morales et al (2020) summarized the impact of water shortage and high temperatures on the photosynthetic apparatus and plant growth. Photosynthetic gas exchange and chlorophyll (Chl) fluorescence parameters, enzymes, and pigments are essential for evaluation of photosynthetic efficiency (Lawlor and Tezara 2009, Gao et al. 2010, Najar et al. 2019, Liguori et al. 2020, You et al. 2020). Some authors reported that different levels of water deficit were not compromised. The parameters reached new homeostatic states after rehydration indicating that adjustments were made to protect them against drought (Vieira et al. 2017). Liu et al. (2018) demonstrated that moderate drought stress

\footnotetext{
Received 3 July 2020, accepted 14 October 2020, published online 16 November 2020.

+Corresponding author; e-mail: biyufenynnd@sina.com, jianghua15@163.com

Abbreviations: A - antheraxanthin; Car - carotenoids; Chl $a(b)$ - chlorophyll $a(b) ; C_{\mathrm{i}}$ - intercellular $\mathrm{CO}_{2}$ concentration; DPS de-epoxidation state; $E$ - transpiration rate; $\mathrm{F}_{0}$ - minimal fluorescence yield of the dark-adapted state; $\mathrm{F}_{0}{ }^{\prime}$ - minimal fluorescence yield of the light-adapted state; $F_{m}$ - maximal fluorescence yield of the dark-adapted state; $F_{m}{ }^{\prime}$ - maximal fluorescence yield of the light-adapted state; $\mathrm{F}_{\mathrm{s}}$ - steady-state fluorescence yield; $\mathrm{F}_{\mathrm{v}} / \mathrm{F}_{\mathrm{m}}$ - maximal quantum yield of PSII photochemistry; $g_{\mathrm{s}}-$ stomatal conductance; HPLChigh performance liquid chromatography; NPQ - nonphotochemical quenching; PEPC - phosphoenolpyruvate carboxylase; $P_{\mathrm{N}}-$ net photosynthetic rate; $\mathrm{q}_{\mathrm{p}}$ - photochemical quenching coefficient; $\mathrm{V}$ - violaxanthin; VAZ - summed concentration of the xanthophyll cycle pigments; $\mathrm{Z}$ - zeaxanthin; $\Phi_{\mathrm{PSII}}$ - actual PSII efficiency.

Acknowledgements: This research was supported by the National Natural Science Foundation of China (31660682), the Key Research and Development Project of Yunnan Province (2018BB002-02), scientific research projects of the Ministry of Natural and Resources, P.R. China (201511003-3), the Open Fund of 'Technical Innovation Team for Land Allocation and Ecological Consolidation in Southwest Diversified Regions' of the Ministry of Natural Resources (YNTD2018KF05) and the Technical Innovation Talents of Yunnan Province (2018HB075).

${ }^{\dagger}$ These authors contributed equally to this work.

Conflict of interest: The authors declare that they have no conflict of interest.
} 
reduced the photochemical activity of PSII whilst that of PSI was unscathed. Thus, the photochemical activity of PSII is more sensitive to drought stress than PSI. Drought or heat stress can influence mesophyll metabolism and reduce photosynthetic rates by decreasing the ribulose1,5-bisphosphate (RuBP) synthesis, Rubisco activity, and carboxylation efficiency (Flexas and Medrano 2002, Lawlor and Cornic 2002, Aranjuelo et al. 2007, Chaves et al. 2009, Lawlor and Tezara 2009, Honoki et al. 2018). Rubisco is the key $\mathrm{CO}_{2}$-fixing enzyme in photosynthesis. This enzyme is also involved in photorespiration and consumed by the plant during photosynthesis. These functions indicate that the loss of net photosynthetic rate $\left(P_{\mathrm{N}}\right)$, which can reach up to $50 \%$ (Lundqvist and Schneider 1991, Ashida et al. 2005, Zhao et al. 2019) demonstrates the important role of phosphoenolpyruvate carboxylase (PEPC) in abiotic stress response at the gene level.

Photoinhibition of photosynthesis can result not only from some form of damage to PSII but also from an increase in thermal energy dissipation (Demmig-Adams and Adams 1992). The xanthophyll cycle is considered to be the main photoprotection method through thermal dissipation (Demmig-Adams 1990, Pfündel and Bilger 1994). Eucalyptus leaves could use the lutein cycle pathway to handle extreme temperatures on daily light radiation (Dhami et al. 2020). Lutein is also involved in the photoprotection of PSII against UV-B-induced oxidative stress (Biswas et al. 2020).

Alfalfa (Medicago sativa L.) is an important leguminous forage that grows in arid and semiarid regions. This forage is mainly planted and dispersed in northern China. At present, alfalfa has been extensively introduced and cultured in southern China to improve the agricultural industry and develop livestock farming. Yunnan province is considered to have the second-largest grassland area in the south and is rich in high-quality forage necessary to improve livestock. The use of alfalfa in Yunnan is mainly limited by the lack of proper varieties of alfalfa capable of adapting to the harsh environment of Yunnan, such as acid- and drought-heat-resistant varieties. Yunnan has abundant natural resources (Bi et al. 2007), but only a few native and introduced species have been studied. The morphological, physiological, and molecular aspects of the species under favourable growth conditions and on a single abiotic factor are emphasised (Bi et al. 2007, $\mathrm{Ma}$ and $\mathrm{Bi} 2011)$. High salinity and drought stress were studied in alfalfa. Zeaxanthin epoxidase gene (MsZEP) was cloned and characterised from alfalfa and expressed in Nicotiana tabacum to verify its function (Zhang et al. 2016), and transgenic alfalfa overexpressing WRKY20 showed increased drought and salt tolerance (Tang et al. 2014). Heat stress considerably affected the photosynthetic activity of alfalfa heat-sensitive cultivars (Wassie et al. 2019). Although the effects of various plants under drought and heat stress have been widely studied, information regarding the combined impacts of the two factors in alfalfa is limited. Previous reports indicated that 'Deqin' alfalfa had high contents of photosynthetic pigments and dominant morphology characteristics (Zhao et al. 2013, Mu et al. 2014, Li et al. 2015). Two varieties of alfalfa were selected to provide additional details and compare photosynthetic traits under drought and heat stress. One hypothesis had been proposed: 'Deqin' alfalfa has a special photoprotection mechanism to tolerate drought and heat stresses and maintain photosynthetic characteristics.

\section{Materials and methods}

Plant material and growth conditions: The seeds of two alfalfa (Medicago sativa L.) varieties ('Deqin' and 'Algonguin') were supplied by the grass laboratory of Yunnan Agricultural University (China) and surfacesterilized by $0.1 \%$ mercuric chloride for $30 \mathrm{~min}$. The sterilized seeds were germinated in a growth chamber under $14 / 10 \mathrm{~h}$ of light/dark at 25 and $18^{\circ} \mathrm{C}$, respectively. After one day, budding seeds were grown in a flower bowl $(10 \times 10 \mathrm{~cm})$ containing a substrate comprising peat soil and red clay $(2: 1, \mathrm{v} / \mathrm{v})$ in the greenhouse at the Horticultural Department of Yunnan Agricultural University. The plants were irrigated with $50 \%$ Hoagland's solution every three or four days until the seedlings grew to $10 \mathrm{~cm}$. Eight seedlings of similar sizes were then transferred to the flower bowls $(12 \times 12 \mathrm{~cm})$, and each variety had 12 replicates. After the plants were grown for $150 \mathrm{~d}$, six pots were randomly selected and exposed to drought and heat stresses.

Well-grown plants (CK) were irrigated with sufficient water and transferred to a growth chamber under controlled environmental conditions $[14 / 10 \mathrm{~h}$ light/dark cycle, $32 / 28^{\circ} \mathrm{C}$ day/night temperature, $30 \%$ relative air humidity, and $150 \mu \mathrm{mol}$ (photon) $\mathrm{m}^{-2} \mathrm{~s}^{-1}$ illumination]. The plants were continuously subjected to drought and heat stresses. The stressed plants were sampled after 4, 8, $12 \mathrm{~d}$ and rehydrated on the $4^{\text {th }} \mathrm{d}$. Unstressed plants served as controls.

Photosynthetic gas exchange and $\mathrm{Chl}$ fluorescence: The net photosynthetic rate $\left[P_{\mathrm{N}}, \mu \mathrm{mol}\left(\mathrm{CO}_{2}\right) \mathrm{m}^{-2} \mathrm{~s}^{-1}\right]$, the stomatal conductance $\left[g_{\mathrm{s}}, \mathrm{mmol}\left(\mathrm{H}_{2} \mathrm{O}\right) \mathrm{m}^{-2} \mathrm{~s}^{-1}\right]$, the intercellular $\mathrm{CO}_{2}\left[C_{\mathrm{i}}, \mu \mathrm{mol}\left(\mathrm{CO}_{2}\right) \mathrm{m}^{-2} \mathrm{~s}^{-1}\right]$, and the transpiration rate $\left[E, \operatorname{mmol}\left(\mathrm{H}_{2} \mathrm{O}\right) \mathrm{m}^{-2} \mathrm{~s}^{-1}\right]$ were measured with $L I-C O R$ 6400 (LI-COR, Lincoln, NE, USA), which is a portable photosynthesis system, and with a LED light source. This experiment was conducted under a light intensity of $800 \mu \mathrm{mol}$ (photon) $\mathrm{m}^{-2} \mathrm{~s}^{-1}, \mathrm{CO}_{2}$ concentration of $400 \mu \mathrm{mol}$ $\mathrm{mol}^{-1}$, and leaf temperature of $25^{\circ} \mathrm{C}$.

The maximum quantum efficiency of PSII photochemistry $\left(\mathrm{F}_{\mathrm{v}} / \mathrm{F}_{\mathrm{m}}\right)$ was measured at room temperature $\left(25^{\circ} \mathrm{C}\right)$ using $L I-C O R \quad 6400$ with an integrated fluorescence chamber $(L I-C O R)$. Following dark adaptation for $2 \mathrm{~h}$, the minimal fluorescence yield of the dark-adapted state $\left(\mathrm{F}_{0}\right)$ was measured by a weak light of $0.5 \mu \mathrm{mol}$ (photon) $\mathrm{m}^{-2} \mathrm{~s}^{-1}$, and the maximal fluorescence yield of the darkadapted state $\left(\mathrm{F}_{\mathrm{m}}\right)$ was determined by a 0.8 -s saturating flash of $8,000 \mu \mathrm{mol}$ (photon) $\mathrm{m}^{-2} \mathrm{~s}^{-1}$ in dark-adapted leaves. The steady-state of fluorescence yield $\left(\mathrm{F}_{\mathrm{s}}\right)$ was recorded, and a second saturating pulse at 8,000 $\mu \mathrm{mol}$ (photon) $\mathrm{m}^{-2} \mathrm{~s}^{-1}$ was imposed to determine the maximal fluorescence yield of the light adapted state $\left(\mathrm{F}_{\mathrm{m}}{ }^{\prime}\right) . \mathrm{F}_{0}{ }^{\prime}$ was the minimal fluorescence yield of the light-adapted state. The parameters were calculated following the $L I-C O R$ 
6400 instrument specifications: maximal quantum yield of PSII photochemistry $\left[\mathrm{F}_{\mathrm{v}} / \mathrm{F}_{\mathrm{m}}=\left(\mathrm{F}_{\mathrm{m}}-\mathrm{F}_{0}\right) / \mathrm{F}_{\mathrm{m}}\right]$, photochemical quenching coefficient $\left[\mathrm{q}_{\mathrm{P}}=\left(\mathrm{F}_{\mathrm{m}}{ }^{\prime}-\mathrm{F}_{\mathrm{s}}\right) /\left(\mathrm{F}_{\mathrm{m}}{ }^{\prime}-\mathrm{F}_{0}{ }^{\prime}\right)\right]$, effective quantum yield of PSII photochemistry $\left[\Phi_{\mathrm{PSII}}=\right.$ $\left.\left(\mathrm{F}_{\mathrm{m}}{ }^{\prime}-\mathrm{F}_{\mathrm{s}}\right) / \mathrm{F}_{\mathrm{m}}{ }^{\prime}\right]$, and nonphotochemical quenching [NPQ = $\left.\mathrm{F}_{\mathrm{m}} / \mathrm{F}_{\mathrm{m}}{ }^{\prime}-1\right]$.

Measurements were made on fully expanded mature leaves of the main stem of 150 d-old alfalfa. The same leaves were used for photosynthetic gas exchange and fluorescence parameters. All measurements were conducted from 08:00 to $11: 30 \mathrm{~h}$ and repeated at least nine times. The leaves were then sampled and immediately frozen in liquid $\mathrm{N}_{2}$. The enzyme crude extract was extracted and stored at $-20^{\circ} \mathrm{C}$ for pigment content and enzyme activity assays. At least three replicate samples were available for each alfalfa type and treatment.

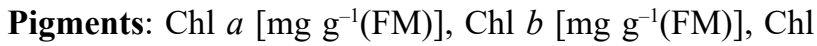
$(a+b)\left[\mathrm{mg} \mathrm{g}^{-1}(\mathrm{FM})\right]$, and carotenoids [Car, $\left.\mathrm{mg} \mathrm{g}^{-1}(\mathrm{FM})\right]$ were determined spectrophotometrically (Agilent Cary 300, Agilent Techologies, Malaysia) using ethanol as a solvent (Yu et al. 2004).

The xanthophyll cycle components in alfalfa leaves, which include violaxanthin $\left[\mathrm{V}, \mu \mathrm{g} \mathrm{g}^{-1}(\mathrm{FM})\right]$, antheraxanthin $\left[\mathrm{A}, \mu \mathrm{g} \mathrm{g}^{-1}(\mathrm{FM})\right]$, and zeaxanthin $\left[\mathrm{Z}, \mu \mathrm{g} \mathrm{g}^{-1}(\mathrm{FM})\right]$, were extracted with acetone and separated by highperformance liquid chromatography. All pigment extraction procedures were conducted in the dark (Wei et al. 2004, Xu et al. 2019). The conversion state of the xanthophyll cycle (DPS) was expressed as a fraction of the total xanthophyll cycle pool: DPS $=(\mathrm{A}+\mathrm{Z}) /(\mathrm{V}+\mathrm{A}+\mathrm{Z})$ (Alonso et al. 2001). The consistent mature leaves were chosen to measure pigments, and three biological replications per variety and treatment were sampled.

Enzyme activities: Fresh leaf material $(0.25 \mathrm{~g})$ was ground into a fine powder using a chilled mortar and pestle with liquid $\mathrm{N}_{2}$. Then, the material was homogenized with $4 \mathrm{~mL}$ of cooled extraction buffer containing $50 \mathrm{mM}$ Tris- $\mathrm{HCl}$ ( $\mathrm{pH} 7.8), 0.01 \%(\mathrm{v} / \mathrm{v})$ Triton $X-100,1 \mathrm{mM}$ EDTA, $10 \mathrm{mM}$ DTT, and $10 \mathrm{mM} \mathrm{MgCl}$ at $0-4^{\circ} \mathrm{C}$. The homogenate was centrifuged at $15,000 \times g$ for $15 \mathrm{~min}$ at $4^{\circ} \mathrm{C}$ according to slightly modified method of Furumoto et al. (2007). The supernatant was stored at $-20^{\circ} \mathrm{C}$ for the analysis of Rubisco and PEPC enzyme activity.

Rubisco (EC 4.1.1.39) was assayed by adding $1.4 \mathrm{~mL}$ of reacting liquid (100 mM Tris- $\mathrm{HCl}, \mathrm{pH} 7.8), 12 \mathrm{mM}$ $\mathrm{MgCl}_{2}$, and $0.4 \mathrm{mM}$ EDTA $\cdot \mathrm{Na}_{2}, 0.2 \mathrm{~mL}$ of $5 \mathrm{mM} \mathrm{NADH}$, $0.2 \mathrm{~mL}$ of $50 \mathrm{mM}$ ATP, $0.2 \mathrm{~mL}$ of $0.2 \mathrm{M} \mathrm{NaHCO}_{3}$, $0.1 \mathrm{~mL}$ of $160 \mathrm{U} \mathrm{mL}^{-1}$ creatine phosphokinase, $0.1 \mathrm{~mL}$ of $160 \mathrm{U} \mathrm{mL} \mathrm{me}^{-1}$ Kennedy oleic acid phosphokinase, $0.1 \mathrm{~mL}$ of $160 \mathrm{U} \mathrm{mL}^{-1}$ glyceraldehyde phosphoric acid dehydrogenase, and $0.3 \mathrm{~mL}$ of distilled water ( $\mathrm{Li} 2000$ ). The Rubisco activity is computed as follows: [ $\mathrm{mmol} \mathrm{mg}^{-1}$ $\left.\min ^{-1}\right]=(\Delta \mathrm{A} \times \mathrm{V}) /\left(2 \times \mathrm{d} \times 6.22 \times \Delta \mathrm{t} \times \mathrm{V}_{\mathrm{E}}\right)$, where $\Delta \mathrm{A}$ denotes the absolute value of the decrease in absorbance at $340 \mathrm{~nm}$ within $3 \mathrm{~min}$ of the reaction; $\mathrm{V}$ denotes the total volume of the reaction system; $\mathrm{d}[\mathrm{cm}]$ denotes the specific optical path; 6.22 denotes the absorbance of NADH at $340 \mathrm{~nm}$ per mole; 2 denotes the oxidation of $2 \mathrm{~mol}(\mathrm{NADH})$ per fixed $1 \operatorname{mol}\left(\mathrm{CO}_{2}\right)$; $\mathrm{t}$ denotes the determination time; and $\mathrm{V}_{\mathrm{E}}$ denotes the volume of the crude enzyme used in the determination.

Phosphoenolpyruvate carboxylase (PEPC, EC 4.1.1.31) activity was assayed by adding $1 \mathrm{~mL}$ of $100 \mathrm{mmol} \cdot \mathrm{L}^{-1}$ Tris- $\mathrm{HCl}$ buffer ( $\mathrm{pH} 7.4$ ), $0.1 \mathrm{~mL}$ of liquid enzyme, $0.1 \mathrm{~mL}$ of $10 \mathrm{~mol} \mathrm{~L}^{-1} \mathrm{MgCl}_{2}, 0.1 \mathrm{~mL}$ of $10 \mathrm{mmol} \mathrm{L}{ }^{-1} \mathrm{NaHCO}_{3}$, $0.2 \mathrm{~mL}$ of $40 \mathrm{mmol} \mathrm{L}^{-1}$ PEP, $0.3 \mathrm{~mL}$ of $1 \mathrm{mg} \mathrm{mL}^{-1} \mathrm{NADH}$ ( $\mathrm{pH} 8.9$ ), and $0.3 \mathrm{~mL}$ of $12 \mathrm{U} \mathrm{mL}^{-1}$ malate dehydrogenase. After mixing the reaction solution, the reaction was initiated with $200 \mu \mathrm{l}$ of PEPC extract after $10 \mathrm{~min}$ preheating in a water bath at $28^{\circ} \mathrm{C}$. The optical density at $340 \mathrm{~nm}$ was determined. The PEPC activity was computed as follows: [mmol $\left.\mathrm{mg}^{-1} \mathrm{~min}^{-1}\right]=(\triangle \mathrm{A} \times \mathrm{V}) /$ $\left(2 \times \mathrm{d} \times 6.22 \times \Delta \mathrm{t} \times \mathrm{V}_{\mathrm{E}}\right)$, where $\triangle \mathrm{A}$ denotes the difference value between pre-reaction and postreaction; $\mathrm{V}$ denotes the total volume of the reaction system; $d$ [cm] denotes the specific optical path; 6.22 denotes the absorbance of $\mathrm{NADH}$ at $340 \mathrm{~nm}$ per micromole; 2 denotes the oxidation of $2 \mathrm{~mol}(\mathrm{NADH})$ per fixed $1 \mathrm{~mol}\left(\mathrm{CO}_{2}\right) ; \triangle \mathrm{T}$ denotes the determination time; and $\mathrm{V}_{\mathrm{E}}$ denotes the volume of the crude enzyme used in the determination.

Statistical analysis: The data were analysed to determine differences between species and treatments for each variable at each sampling time. All the data were subjected to analysis of variance ( $A N O V A$ ), and the significant differences between means were determined by Tukey's test at $P<0.05$ level. Statistical tests were also performed using SPSS 20.0 software (IBM, NY, USA), and graphs and regression coefficients were plotted and calculated with SigmaPlot 10.0 software (Systat Software, Inc., Richmond, CA, USA).

\section{Results}

Leaf gas exchange: The variations in gas-exchange parameters in alfalfa leaf under drought and heat stresses are shown in Fig. 1. The values of $P_{\mathrm{N}}$ and $E$ demonstrated decreasing tendencies under stress. The $P_{\mathrm{N}}$ decreased by 89.3 and $73.8 \%$ in 'Deqin' and 'Algonguin', respectively, compared with those in the control groups on the $12^{\text {th }} \mathrm{d}$. Additionally, no significant change was found in the $P_{\mathrm{N}}$ in 'Algonguin' between the $8^{\text {th }}$ and $12^{\text {th }} \mathrm{d}$. Furthermore, the $P_{\mathrm{N}}$ of 'Deqin' was significantly higher than that of 'Algonguin' CK on the $8^{\text {th }} \mathrm{d}$ but was significantly lower than that of 'Algonguin' on the $12^{\text {th }}$ and the $4^{\text {th }} \mathrm{d}$ after rehydration (Fig. 1A). The $E$ decreased by 33.6 and $72.2 \%$ in 'Deqin' and 'Algonguin', respectively, on the $12^{\text {th }} \mathrm{d}$, compared with those in the control groups. Additionally, no significant differences were found in the $E$ in 'Deqin' between $\mathrm{CK}$ and the $4^{\text {th }} \mathrm{d}$ stresses. Furthermore, the $E$ of 'Algonguin' was significantly higher than that of 'Deqin' CK on the $4^{\text {th }} \mathrm{d}$ and the $8^{\text {th }} \mathrm{d}$ but was significantly lower than that of 'Algonguin' on the $12^{\text {th }} \mathrm{d}$ (Fig. $1 C$ ). The $C_{\mathrm{i}}$ in 'Deqin' showed a trend of rapidly falling first and then rising with the stress duration, and 'Deqin' was significantly higher than that of 'Algonguin' on the $12^{\text {th }} \mathrm{d}$ and rehydration (Fig. 1B). The $g_{\mathrm{s}}$ in 'Algonguin' alfalfa showed a decreasing tendency under stresses, and 'Algonguin' was significantly 


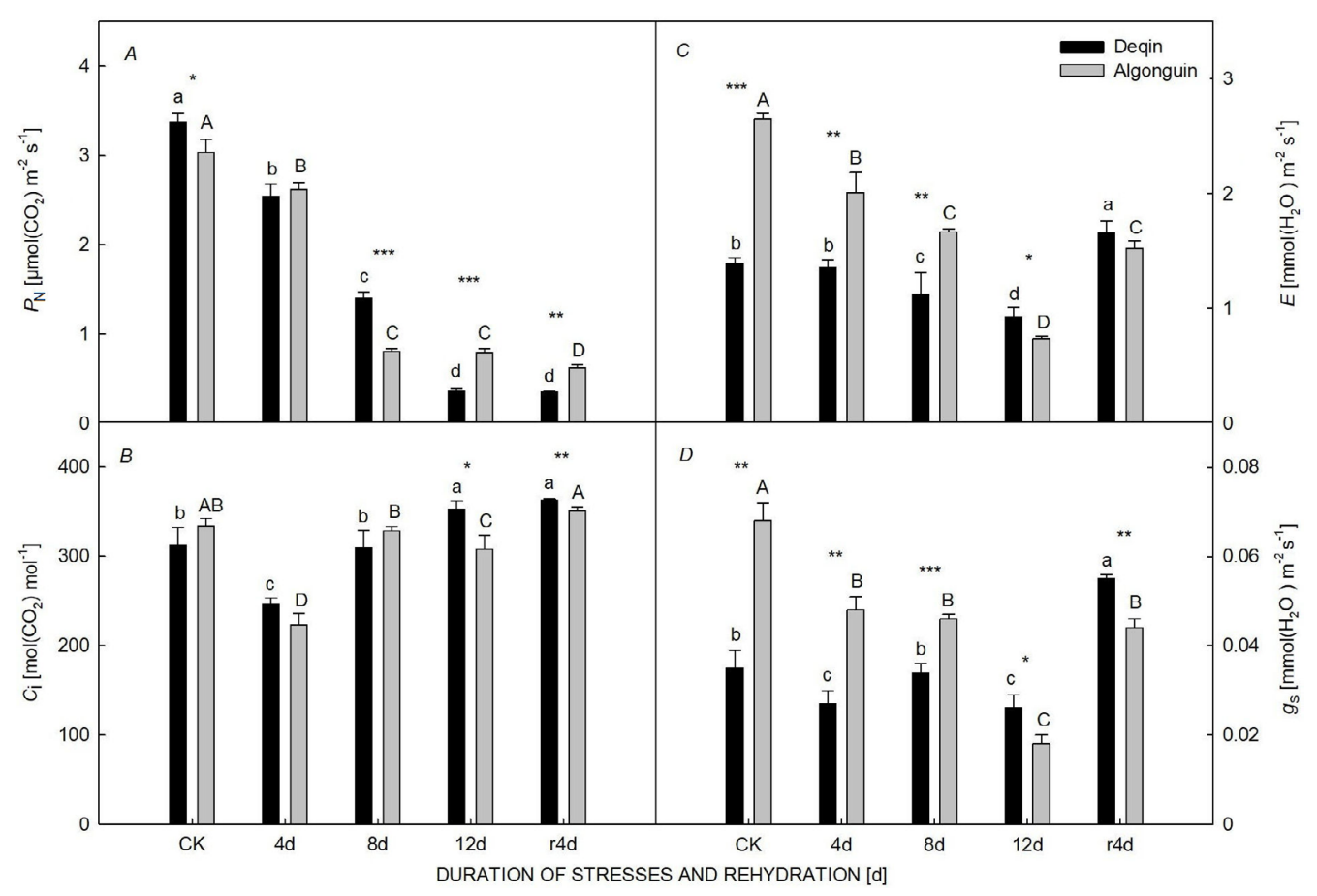

Fig. 1. Gas-exchange parameters in alfalfa under different treatments: $\mathrm{CK}$, well-grown plants at normal temperature and irrigated with sufficient water; days 4,8 , and 12 of stresses; rehydration on the $4^{\text {th }}$ day $(\mathrm{r} 4 \mathrm{~d}) .(A) P_{\mathrm{N}}-$ net photosynthetic rate, $(B) C_{\mathrm{i}}-$ intercellular $\mathrm{CO}_{2},(C) E$ - transpiration rate, $(D) g_{\mathrm{s}}$ - stomatal conductance. Values are the mean $\pm \mathrm{SD}$ of three replicates per varieties and treatment. * indicates statistical difference $(P<0.05)$ under the same treatment between different varieties for each parameter: ${ }^{*} P<0.05 ;{ }^{* *} P<0.01$; ${ }^{* * *} P<0.001$. Different lowercase and uppercase letters denote statistical differences by the Duncan's test $(P<0.05)$ in 'Deqin' and 'Algonguin' varieties, respectively, for each parameter.

higher than that of 'Deqin' CK on the $4^{\text {th }} \mathrm{d}$ and the $8^{\text {th }} \mathrm{d}$. However, 'Deqin' was significantly higher than that of 'Algonguin' on the $12^{\text {th }} \mathrm{d}$ and rehydration (Fig. 1D).

Chl fluorescence: Drought and heat stresses had negative effects on $\mathrm{F}_{\mathrm{v}} / \mathrm{F}_{\mathrm{m}}, \mathrm{q}_{\mathrm{P}}$, and $\Phi_{\mathrm{PSII}}$ (Fig. $2 A-C$ ) but NPQ values showed an increasing trend (Fig. 2D). The values of $\mathrm{F}_{\mathrm{v}} / \mathrm{F}_{\mathrm{m}}, \mathrm{q}_{\mathrm{P}}$, and $\Phi_{\mathrm{PSII}}$ in 'Deqin' significantly decreased by $18.4,71.5$, and $81.8 \%$, respectively, on the $12^{\text {th }} \mathrm{d}$ of drought and heat stresses compared to the control. The values in 'Algonguin' decreased by $16.6,85.1$, and $88.8 \%$ on the $12^{\text {th }} \mathrm{d}$ compared to the control. $\mathrm{F}_{\mathrm{v}} / \mathrm{F}_{\mathrm{m}}$ in 'Deqin' was significantly lower than that in 'Algonguin' on the $8^{\text {th }} \mathrm{d}$. The values of $\mathrm{q}_{\mathrm{P}}$ and $\Phi_{\mathrm{PSII}}$ in 'Deqin' were higher than those in 'Algonguin' on the $4^{\text {th }}$ and $12^{\text {th }} \mathrm{d}$ but lower than that of 'Algonguin' on the $8^{\text {th }} \mathrm{d}$. The values of NPQ in the two varieties increased by 97.7 and $34.1 \%$ in 'Deqin' and 'Algonguin', respectively, on the $12^{\text {th }} \mathrm{d}$, compared with those in the control groups. The NPQ in 'Deqin' was significantly higher than in 'Algonguin' on the $8^{\text {th }}$ and $12^{\text {th }} \mathrm{d}$.

Enzyme activities: The effect of stresses on Rubisco activity in both varieties showed a trend of first declining and then rising, demonstrating a minimum reduction on the $8^{\text {th }} \mathrm{d}$. Rubisco activity of 'Deqin' decreased to the minimum by $47.5 \%$ compared with the control and in 'Algonguin', 50\% reduction occurred. The Rubisco activity in 'Deqin' was significantly higher than that in 'Algonguin' $\mathrm{CK}$ at the $4^{\text {th }}$ and $8^{\text {th }} \mathrm{d}$ and after rehydration (Fig. $3 A$ ). The PEPC activity significantly increased on the $12^{\text {th }} \mathrm{d}$ by 105.6 and $34.4 \%$ in 'Deqin' and 'Algonguin' alfalfa, respectively, compared with that in the control groups. The maximum value of 'Deqin' was significantly higher than that of 'Algonguin' on the $12^{\text {th }} \mathrm{d}$ (Fig. $3 B$ ).

Photosynthetic pigment content: No differences were found between the two varieties in $\mathrm{Chl}(a+b)$ and the ratio of Chl $a / b$ (Fig. $4 A, B$ ). Stresses caused an increase in Chl $(a+b)$ by $80.3 \%$ in 'Deqin' and $43.8 \%$ 'in Algonguin' on the $8^{\text {th }} \mathrm{d}$ and then decreased to the control level. The ratio of Chl $a / b$ in 'Deqin' decreased to a minimum by $31.4 \%$ on the $12^{\text {th }} \mathrm{d}$, whilst that of 'Algonguin' decreased to a minimum by $35.5 \%$ on the $8^{\text {th }} \mathrm{d}$. The Car and the ratio of $\mathrm{Car} / \mathrm{Chl}(a+b)$ in the two varieties demonstrated an almost eight-fold increase on the $4^{\text {th }} \mathrm{d}$. The Car content in 'Deqin' significantly increased by $8.8 \%$ on the $8^{\text {th }} \mathrm{d}$ and then sharply decreased by $82.3 \%$ on the $12^{\text {th }} \mathrm{d}$. However, the Car content in 'Algonguin' decreased by $23.5 \%$ on the $8^{\text {th }} \mathrm{d}$ and then revealed no significant changes. Meanwhile, the Car content in 'Deqin' was significantly higher than that in 'Algonguin' on the $8^{\text {th }} \mathrm{d}$ and significantly lower than that in 'Algonguin' on the $12^{\text {th }} \mathrm{d}$ (Fig. 4C). The ratio of $\mathrm{Car} / \mathrm{Chl}(a+b)$ in 'Deqin' decreased by $76.5 \%$ from the $4^{\text {th }}$ to the $12^{\text {th }} \mathrm{d}$. It was significantly higher and lower in 'Deqin' than in 'Algonguin' on the $8^{\text {th }}$ and $12^{\text {th }} \mathrm{d}$, respectively. The 


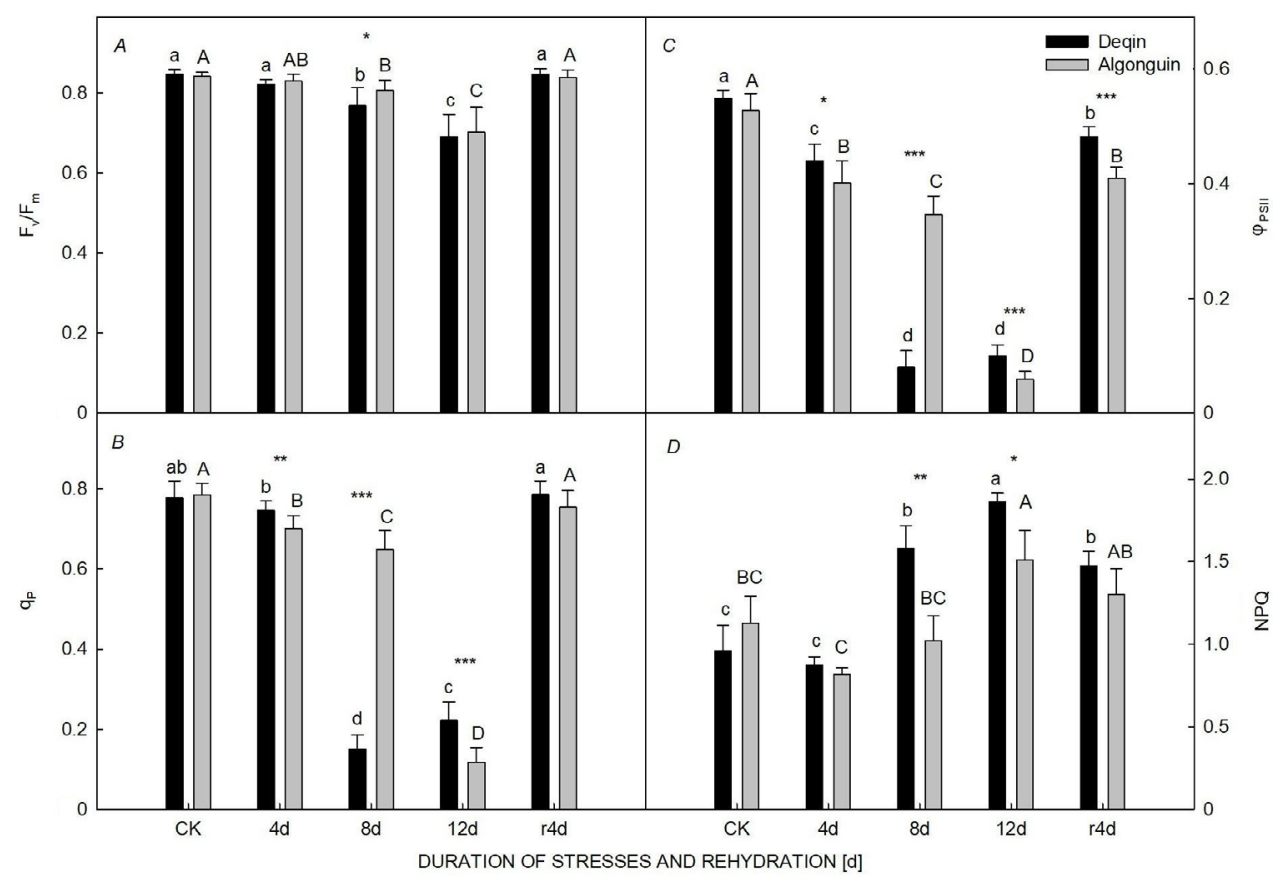

Fig. 2. Chlorophyll fluorescence parameters in alfalfa under different treatments: CK, well-grown plants at normal temperature and irrigated with sufficient water; days 4,8 , and 12 of stresses; rehydration on the $4^{\text {th }}$ day (r4d). $(A) \mathrm{F}_{\mathrm{v}} / \mathrm{F}_{\mathrm{m}}-$ maximal quantum yield of PSII photochemistry, $(B) \mathrm{q}_{\mathrm{P}}$ - photochemical quenching coefficient, $(C) \Phi_{\mathrm{PSII}}$ - effective quantum yield of PSII photochemistry, $(D)$ NPQ nonphotochemical quenching. Values are the mean $\pm \mathrm{SD}$ of nine replicates per varieties and treatment. * indicates statistical difference $(P<0.05)$ under the same treatment between different varieties for each parameter: ${ }^{*} P<0.05 ;{ }^{* *} P<0.01 ;{ }^{* * *} P<0.001$. Different lowercase and uppercase letters denote statistical differences by the Duncan's test $(P<0.05)$ in 'Deqin' and 'Algonguin' varieties, respectively, for each parameter.

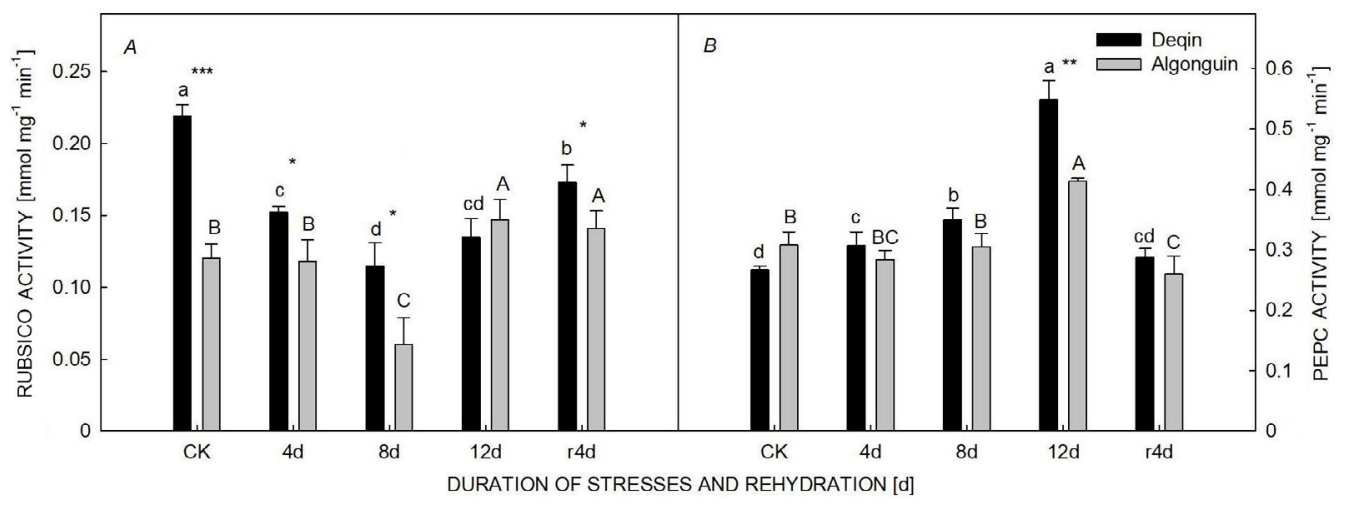

Fig. 3. Rubisco activity $(A)$ and phosphoenolpyruvate carboxylase (PEPC) activity $(B)$ in alfalfa under different treatments: CK, wellgrown plants at normal temperature and irrigated with sufficient water; days 4,8 , and 12 of stresses; rehydration on the $4^{\text {th }}$ day ( $\mathrm{r} 4 \mathrm{~d}$ ). Values are the mean $\pm \mathrm{SD}$ of three replicates per varieties and treatment. * indicates statistical difference $(P<0.05)$ under the same treatment between different varieties for each parameter: ${ }^{*} P<0.05 ;{ }^{* *} P<0.01 ;{ }^{* * *} P<0.001$. Different lowercase and uppercase letters denote statistical differences by the Duncan's test $(P<0.05)$ in 'Deqin' and 'Algonguin' varieties, respectively, for each parameter.

$\mathrm{Car} / \mathrm{Chl}(a+b)$ ratio in 'Algonguin' was reduced by $37.0 \%$ on the $8^{\text {th }} \mathrm{d}$ and increased by $41.3 \%$ on the $12^{\text {th }} \mathrm{d}$ compared with the previous stage (Fig. $4 D$ ).

Xanthophyll cycle: The ratios of DPS first increased and then decreased by 76.5 and $67.6 \%$, respectively, and were significantly higher on the $12^{\text {th }} \mathrm{d}$ compared with CK. DPS of 'Deqin' was significantly higher than that of 'Algonguin' on the $8^{\text {th }}$ and $12^{\text {th }} \mathrm{d}$ (Fig. 5D). No significant differences were observed between the two varieties in $\mathrm{V}$ content. Both varieties demonstrated reductions of 82.6 and $62.4 \%$ on the $12^{\text {th }} \mathrm{d}$ (Fig. 5A). The $\mathrm{Z}$ content in 'Deqin' significantly decreased by $71.0 \%$, which was higher than that of 'Algonguin' at the $4^{\text {th }} \mathrm{d}$ and then significantly increased by $262 \%$ on the $8^{\text {th }} \mathrm{d}$. The $\mathrm{Z}$ content in 'Algonguin' significantly decreased by $68.5 \%$ and then increased under stresses by $96.0-106.7 \%$ (Fig. $5 B$ ). The violaxanthin to zeaxanthin conversion rates under stresses 


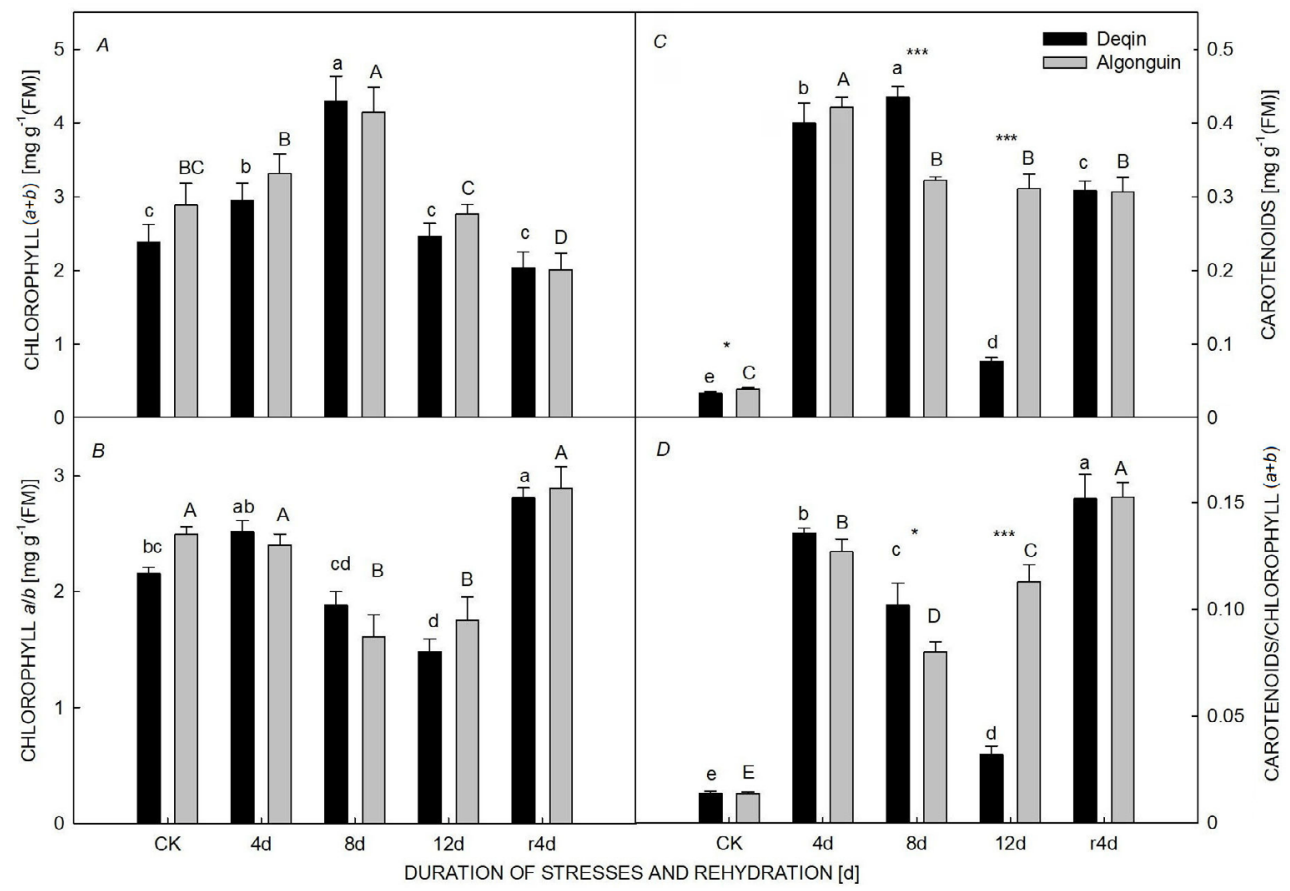

Fig. 4. Changes in chlorophyll (Chl) $(a+b)(A), \mathrm{Chl} a / b(B)$, carotenoids (Car) $(C)$, and Car/Chl $(a+b)(D)$ of alfalfa under different treatments: $\mathrm{CK}$, well-grown plants at normal temperature and irrigated with sufficient water; days 4,8 , and 12 of stresses; rehydration on the $4^{\text {th }}$ day $(\mathrm{r} 4 \mathrm{~d})$. Values are the mean $\pm \mathrm{SD}$ of three replicates per varieties and treatment. * indicates statistical difference $(P<0.05)$ under the same treatment between different varieties for each parameter: ${ }^{*} P<0.05 ;{ }^{* * *} P<0.001$. Different lowercase and uppercase letters denote statistical differences by the Duncan's test $(P<0.05)$ in 'Deqin' and 'Algonguin' varieties, respectively, for each parameter.

were $2.3-41.0 \%$ ('Deqin') and 2.6-25.2\% ('Algonguin'), respectively, under each treatment conditions. This finding demonstrated that the stress enhanced zeaxanthin content and the xanthophyll de-epoxidation state.

Relationships between NPQ and xanthophyll cycle: A significantly linear and negative relationship of NPQ with $\mathrm{V}$ content $\left(\mathrm{Y}_{1}=-9.6712 \mathrm{X}+24.9149, R_{1}{ }^{2}=0.6016\right.$, $P<0.01 ; \mathrm{Y}_{2}=-10.9259 \mathrm{X}+24.6132, R_{2}{ }^{2}=0.5897, P<0.01$ ) under stresses was observed in 'Deqin' and 'Algonguin', respectively (Fig. $6 A$ ). The NPQ was linearly and positively correlated with $\mathrm{Z}$ content $\left(\mathrm{Y}_{1}=0.5299 \mathrm{X}+0.1345, R_{1}{ }^{2}=\right.$ $0.3105, P<0.01 ; \mathrm{Y}_{2}=1.2126 \mathrm{X}-0.5694, R_{2}^{2}=0.4947$, $P<0.01)$ and DPS $\left(\mathrm{Y}_{1}=26.1322 \mathrm{X}-20.3142, R_{1}{ }^{2}=0.5896\right.$, $\left.P<0.01 ; \mathrm{Y}_{2}=30.1872 \mathrm{X}-22.5331, R_{2}{ }^{2}=0.6189, P<0.01\right)$ in the two varieties under drought and heat stresses (Fig. 6B,C).

\section{Discussion}

In the present study, $P_{\mathrm{N}}, E$, and $g_{\mathrm{s}}$ decreased with the increase in drought and heat stresses, whilst the $C_{\mathrm{i}}$ increased in the two varieties under the stresses. These results are consistent with those of previous studies on the effects of drought and heat stresses on the photosynthetic characteristics of alfalfa (Mu et al. 2014). Under drought stress, stomatal closure was observed by detailed studies that indicated declined $g_{\text {s. }}$. Drought stress causes the closure of the stomata, impairs the mesophyll cell, and reduces the activity of the photosynthetic enzyme and $P_{\mathrm{N}}$ (Lawlor and Cornic 2002). A previous study on the combined effect of drought and heat stresses in Arabidopsis revealed that the stomata opened and increased respiration and simultaneously inhibited photosynthesis (Rizhsky et al. 2004). High temperatures caused $60 \%$ inhibition of photosynthesis by as much as $30 \%$ stomatal closure in the grape (Vitis vinifera), and $g_{\mathrm{s}}$ and $C_{\mathrm{i}}$ could be remarkably affected under high temperatures (Greer and Weedon 2012). Interestingly, the present results showed that $g_{s}$ continuously decreased under stress for 'Algonguin' but slightly increased for 'Deqin' on day 8. This trend is possibly attributed to the different leaves, which may have specific influence on $g_{s}$. This phenomenon is also consistent with increased leaf stomatal conductance under heat stress in the grapes (Tzortzakis et al. 2020). $P_{\mathrm{N}}, E$, and $g_{\mathrm{s}}$ severely decreased when the two varieties were subjected to water deficit and heat stress (Fig. 1A). This finding was consistent with the common observations on single stress factors, such as drought or heat stress, and the combination of drought and heat stresses (Jiang and Huang 2001, Rizhsky et al. 2002). However, the two varieties exhibited different decreasing trends. Comparing the $8^{\text {th }}$ and $12^{\text {th }} \mathrm{d}$, the $P_{\mathrm{N}}$ of 'Deqin' $(45.0 \%)$ decreased to a lesser extent than that of 'Algonguin' (69.1\%). Conversely, $P_{\mathrm{N}}$ of 'Deqin' (74.3\%) decreased to a higher extent than that of 'Algonguin' (1.5\%) from days $8-12$ probably because 'Deqin' can easily adapt to moderate stress conditions. However, 'Deqin' might wither under remarkably severe drought and heat stresses. Although 'Deqin' can thrive well in the dry-hot valley, a large proportion is spread near the 


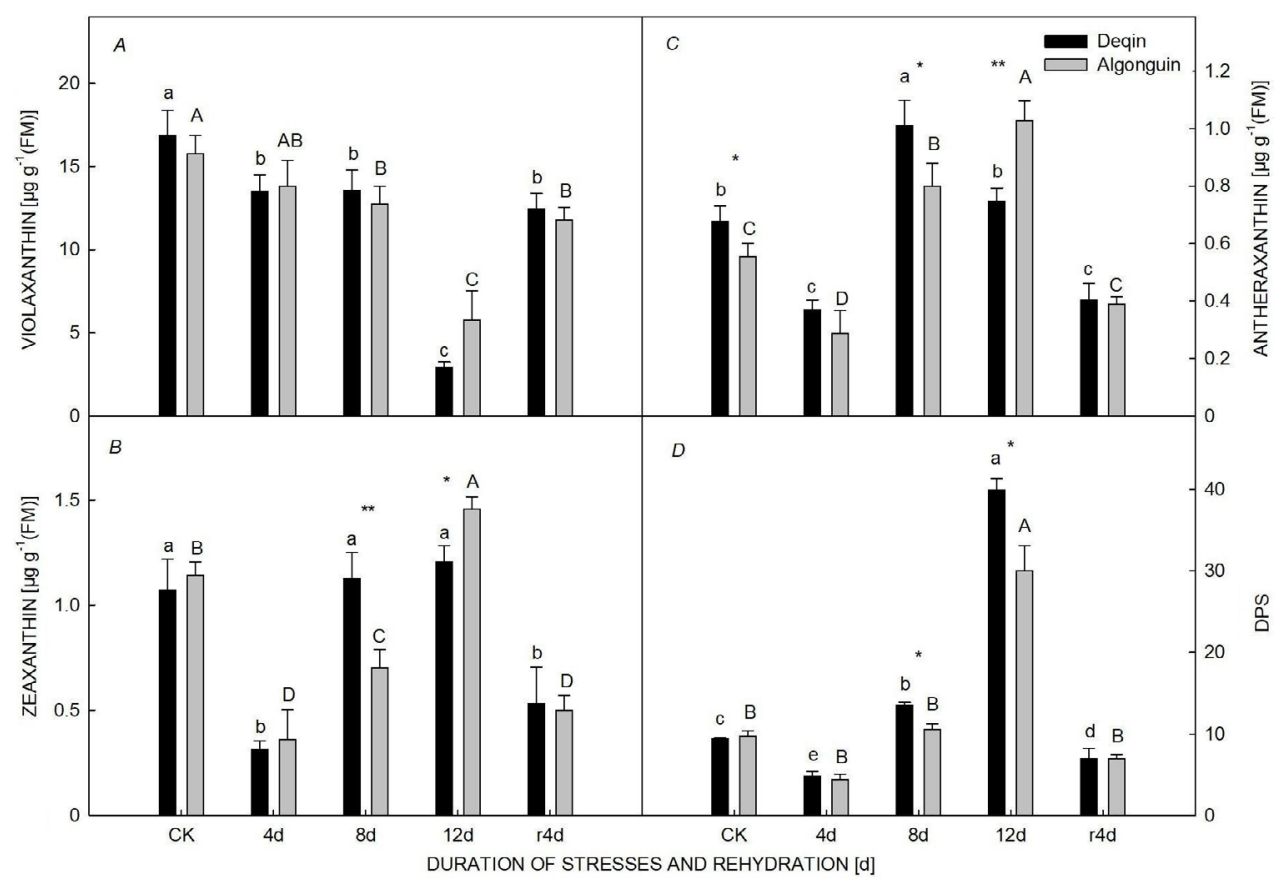

Fig. 5. $(A)$ Violaxanthin, $(B)$ zeaxanthin, and $(C)$ antheraxanthin content. $(D)$ The conversion state of the xanthophyll cycle (DPS) was expressed as a fraction of the total xanthophyll cycle pool: DPS $=(\mathrm{A}+\mathrm{Z}) /(\mathrm{V}+\mathrm{A}+\mathrm{Z})$ in alfalfa under different treatments: CK, well-grown plants at normal temperature and irrigated with sufficient water; days 4,8 , and 12 of stresses; rehydration on the $4^{\text {th }}$ day $(\mathrm{r} 4 \mathrm{~d})$. Values are the mean $\pm \mathrm{SD}$ of three replicates per varieties and treatment. $*$ indicates statistical difference $(P<0.05)$ under the same treatment between different varieties for each parameter: ${ }^{*} P<0.05 ;{ }^{* * *} P<0.001$. Different lowercase and uppercase letters denote statistical differences by the Duncan's test $(P<0.05)$ in 'Deqin' and 'Algonguin' varieties, respectively, for each parameter.

waterhead (Bi 2007). Under drought and heat stresses, the average decrease of A in 'Algonguin' (32.3\%) was more evident than that in 'Deqin' (Fig. 1C), where one main contributing factor was the large leaf area of 'Algonguin' (Zhao et al. 2013). In 'Deqin' and 'Algonguin' alfalfa, the reduction in $P_{\mathrm{N}}$ in stressed plants was probably caused by stomatal closure under mild stress and low $g_{\mathrm{s}} . C_{\mathrm{i}}$ is considered to be an important index of photosynthesis. A relationship between $P_{\mathrm{N}}$ and $C_{\mathrm{i}}$ under stress was found; that is, $P_{\mathrm{N}}$ and $C_{\mathrm{i}}$ simultaneously decreased (Wang et al. 2011) However, another study revealed that the variation between the two indices follows an opposite trend (Sánchez-Rodríguez et al. 1999). The result of the present study was similar to the latter. On the $4^{\text {th }} \mathrm{d}, P_{\mathrm{N}}$ and $C_{\mathrm{i}}$ decreased in both varieties. The $C_{\mathrm{i}}$ constantly increased in 'Deqin' with increasing stress. However, the $C_{\mathrm{i}}$ of 'Algonguin' exhibited increments for a short time and then gradually declined. Several reasons for this variation are presented. The inhibitory effects of drought on photosynthesis can be associated with low $\mathrm{CO}_{2}$ availability caused by limited diffusion through the stomata and mesophyll (Flexas et al. 2004) or alterations in carbon assimilation metabolism (Lawlor and Cornic 2002). Numerous studies under drought stress showed that stomatal factors accounted for the decline in $P_{\mathrm{N}}$ under light and moderate drought stresses, whereas leaf $P_{\mathrm{N}}$ decreased mainly due to nonstomatal factors under severe drought stress (Liang et al. 2019). The $P_{\mathrm{N}}$ diminished without a decrease in intercellular $\mathrm{CO}_{2}$ concentration during the early senescence of flag leaves. This phenomenon indicates that low photosynthetic capacity is not caused by stomatal limitation but by reduced carboxylation efficiency (Weng et al. 2005). Therefore, under mild and moderate stresses, the stomatal limitation is the main factor, whereas the nonstomatal limitation affected photosynthesis during severe stress for both varieties.

The Chl content is one of the major factors affecting photosynthetic capacity. Drought stress leads to the decrease in Chl $a$ but an increase in Chl $b$ and total Chl (Hassanzadeh et al. 2009). Illumination of cucumber seedlings under heat stress conditions resulted in inhibition of Chl biosynthesis by 60\% (Tewari and Tripathy 1998). $\mathrm{Chl}$ content and the ratio of $\mathrm{Chl} a / b$ were significantly reduced under drought stress (Alonso et al. 2001, Lu et al. 2002, Guo et al. 2005, Liu et al. 2011, Rai et al. 2011). Heat stress significantly reduced the Chl content of heat-sensitive alfalfa cultivars (Wassie et al. 2019). Similar results were also found in this study, in which Chl $a / b$ ratio significantly decreased in the two varieties. Liu et al. (2011) found that the ratio of Car/Chl $(a+b)$ significantly increased under drought stress in six woody plant species. In this study, prolonged drought and heat stresses significantly decreased the ratio of Car/Chl $(a+b)$ in 'Deqin', thereby indicating that severe stresses need high photoprotection by Car. Car played an important function in facilitating photoprotection and reducing photooxidation damage of leaves from plants exposed to certain stress. Therefore, carotenoids (Fig. 4C,D) and violaxanthin content (Fig. $5 A$ ) decreased under severe stresses in 'Deqin'. 


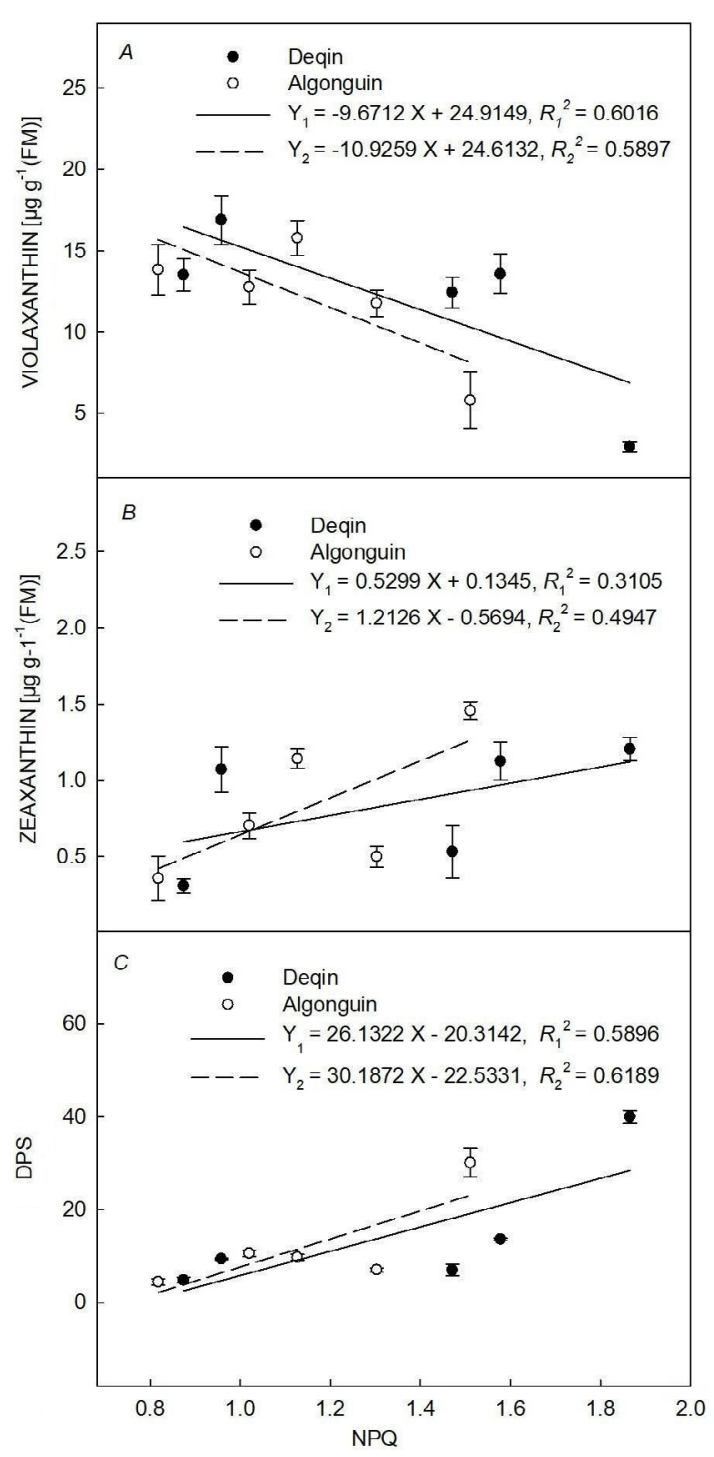

Fig. 6. (A) Correlations between nonphotochemical quenching (NPQ) and xanthophyll cycle components of violaxanthin content, $(B)$ correlations between de-epoxidation state (DPS) and zeaxanthin content, $(C)$ correlations between NPQ and DPS. Values are the mean \pm SD of three replicates per varieties and treatment. 'Deqin' (solid circle, solid line) and 'Algonguin' (open circle, dashed line), $R_{1}{ }^{2}$ and $R_{2}{ }^{2}$, respectively, denote the regression coefficients.

Numerous studies on Rubisco under drought stress have been conducted but the reported results of Rubisco activity are distinctly different. The main effects include sharply decreased Rubisco activity (Majumdar et al. 1991, Parry et al. 2002, Flexas et al. 2006), and even no effect (Panković et al. 1999). Changes in Rubisco activity have also been debated and attributed to the differences in drought intensity (Flexas et al. 2006). In this study, both varieties showed a trend of first declining and then rising, and the results were similar to those in Kalidium foliatum (Gong et al. 2018), where Rubisco activity was steadily reduced and increased at low and high salt concentrations, respectively. $\mathrm{PEPC}$ is a key enzyme for $\mathrm{CO}_{2}$ fixation in
CAM, $\mathrm{C}_{3}$, and $\mathrm{C}_{4}$ plants. $P P C 2$ gene is considered as the major gene encoding PEPC enzyme in Arabidopsis, the PPC2 mutants suffered a growth arrest under low atmospheric $\mathrm{CO}_{2}$ conditions (You et al. 2020). The higher level of PEPC activity in saline-affected plants compared with that in the control plants suggested PEPC enzyme regulation in the adaptation of plants to saline environments (García-Mauriño et al. 2003). Parental Spartina lines had different strategies at the PEPC level to cope with salinity with high PEPC activity under high salinity, but hybrids showed constant PEPC apparent specific activity from fresh water to hypersalinity (Gallego-Tévar et al. 2020a,b). Daloso et al. (2015) provided a qualitative demonstration that tobacco (Nicotiana tabacum) guard cells fixed $\mathrm{CO}_{2}$ using Rubisco and PEPC. Rubisco and PEPC activities of soybean leaves were reduced by drought stress. However, high activities of Rubisco and PEPC could maintain high photosynthetic performance (Hao et al. 2013). Rubisco and PEPC enzymes presented different trends in this study, and in 'Deqin' was higher than that of 'Algonguin' alfalfa under varying degrees of stresses. Thus, this trend of change may be due to the intensity of drought and heat stresses and the tolerance of species.

The Chl fluorescence was used as a nondestructive screening method to discriminate susceptibility and resistance to salt stress in alfalfa (Najar et al. 2019). Waterlogging stress caused a significant reduction in Chl content, $\mathrm{F}_{\mathrm{v}} / \mathrm{F}_{\mathrm{m}}$, and $P_{\mathrm{N}}$ in alfalfa (Zhang et al. 2019). High temperatures might significantly reduce the value of NPQ in tomato (Solanum lycopersicum) (Gerganova et al. 2016). In this study, two alfalfas were substantially inhibited under mild and severe stresses (Fig. 2A). A significant reduction in $\mathrm{F}_{\mathrm{v}} / \mathrm{F}_{\mathrm{m}}$ indicates photoinhibition due to a low proportion of open reaction centres (Redondo-Gómez et al. 2007). The results in present study showed a substantial decrease in $\mathrm{F}_{\mathrm{v}} / \mathrm{F}_{\mathrm{m}}$ under stresses indicating of photoinhibition caused by stresses. $F_{v} / F_{m}$ then returned to the control level after rehydration, which may suggest that the undamaged PSII apparatus can sustain the light capture. The xanthophyll cycle induced by drought and heat could dissipate excess energy but is insufficient to prevent the induced reduction in the $\mathrm{Chl}$ content, as shown in Fig. $3 A$. The xanthophyll cycle is a reversible process through violaxanthin, antheraxanthin and zeaxanthin, which are interconverted to balance light absorption with the capacity to use the energy to drive photosynthetic reactions. Along with the activation of the xanthophyll cycle pool by drought and high temperature, a significant de-epoxidation state of violaxanthin via the intermediate antheraxanthin led to the formation of zeaxanthin. Therefore, violaxanthin contents considerably decreased ('Deqin' 82.6\%, 'Algonguin' 63.4\%) on the $12^{\text {th }} \mathrm{d}$ of treatment in the two alfalfa varieties. Simultaneously, the conversion state of the xanthophyll cycle (DPS) substantially increased ('Deqin' 76.5\%, 'Algonguin' $68.3 \%$ ). The decrease in light absorbance possibly due to the reduced pigment contents, especially carotenoids and lutein, contributed to photoprotection. The role of zeaxanthin and the xanthophyll cycle in photoprotection, which is based on fluorescence quenching measurements, 
has a good correlation to the amount of zeaxanthin (and antheraxanthin) (Eskling et al. 1997, Gilmore 2001). The results confirmed that downhill energy transfer is possible from Chl $a$ to V, Z, and A (Frank et al. 2000). A significant positive correlation was found between $\mathrm{q}_{\mathrm{P}}$ and $\mathrm{V}$ or VAZ contents, whilst the correlation between $\mathrm{q}_{\mathrm{P}}$ and $\mathrm{A}$ and $\mathrm{Z}$ content and DPS was negative. A relationship between zeaxanthin formation and nonphotochemical energy dissipation was also observed (Gilmore and Yamamoto 1993, Pfündel and Bilger 1994). The NPQ was significantly positively correlated with $Z$ contents and DPS and negatively correlated with $\mathrm{V}$ and VAZ contents. The interconversion of violaxanthin and zeaxanthin controls the xanthophyll cycle pool size to optimise the kinetics of NPQ (Johnson et al. 2008). Thus, the xanthophyll cycle might have a central role in photoprotection under drought and heat stress conditions in alfalfa. The mechanism of thermal dissipation by the xanthophyll cycle in alfalfa must be further studied.

Climate change will increase heat and drought stresses in many dryland areas, which could negatively affect the photosynthetic capacity. The interactive impacts of warming and rainfall reduction on plant performance were generally smaller than those expected from additive single-factor effects (León-Sánchez et al. 2020). Drought and heat stresses significantly affected physiological and biochemical parameters of the examined grapevine cultivars (Tzortzakis et al. 2020). Das et al. (2016) investigated the regulation of various molecular processes and found altered signaling due to drought and heat stresses in the leaves of two soybean varieties (Glycine max L., cultivars Surge and Davison). A correlation of peroxisome abundance with physiological responses and yield under heat, drought, and heat plus drought stresses was observed in eight genotypes of quinoa (Chenopodium quinoa Willd) (Hinojosa et al. 2019). Simultaneous application of heat and drought revealed similar physiological responses as to the drought stress in tomato (Solanum lycopersicum) (Zhou et al. 2017). Heat and drought stresses limited the growth and production potential of lentil (Lens culinaris), individually or in combination, and damaged cell membranes, photosynthetic traits, and water relations. These effects were more severe than the combined stress (Sehgal et al. 2017). Plant adaptation to drought stress included the closure of stomata and the reduction in plant photosynthetic rates. Although heat stress had milder effects compared with drought stress, the combined negative effects of the two stresses remain unknown (Tzortzakis et al. 2020). Sattar et al. (2020) investigated individual and combined effects of terminal drought and heat stresses on photosynthetic pigments, osmolyte accumulation, and antioxidant defence mechanism in the flag leaf of bread wheat (Triticum aestivum). The interactive effect of both stresses was hypoadditive. However, the effect of one stress neutralized the other for some traits, such as turgor potential and ascorbate peroxidase (APX, EC 1.11.1.11) (Sattar et al. 2020). Gas exchange, Chl fluorescence parameters, pigments, and enzymes in this study were influenced by the combination of drought and heat stresses. These indicators measured rehydration and rewarming after the $4^{\text {th }} \mathrm{d}$ because the alfalfa characteristics returned to the control level. However, the photosynthetic capacities were not rapidly recovered, especially $P_{\mathrm{N}}$, from severe drought and heat stress. Thus, the relationships between stresses and resilience require further study. The photoinhibition in the two varieties of alfalfa was caused by drought and heat stresses, which have obvious changes in photosynthetic efficiency. As a native variety, 'Deqin' provides an important resource for adaptation to the moderate drought and heat stress conditions. Meanwhile, as an introduced variety, 'Algonguin' was suitable for severe stressful conditions. However, the mechanism for adaptation to changing climatic conditions remains unexplored.

Conclusions: This study highlighted that drought and heat stress-induced decrease in photosynthetic efficiency and pigments content in two alfalfa varieties ('Deqin' and 'Algonguin') might not represent damage but rather an adaption mechanism to abiotic stresses. The accumulation of carotenoids and violaxanthin decreased significantly, and there was a significant correlation between heat dissipation and xanthophyll cycle under drought and heat conditions. The evidence warrants further investigation of xanthophyll contribution to photoprotection which played a significant role under drought and heat stresses in two alfalfa varieties.

\section{References}

Alonso R., Elvira S., Castillo F.J., Gimeno B.S.: Interactive effects of ozone and drought stress on pigments and activities of antioxidative enzymes in Pinus halepensis. - Plant Cell Environ. 24: 905-916, 2001.

Aranjuelo I., Irigoyen J.J., Sánchez-Díaz M.: Effect of elevated temperature and water availability on $\mathrm{CO}_{2}$ exchange and nitrogen fixation of nodulated alfalfa plants. - Environ. Exp. Bot. 59: 99-108, 2007.

Ashida H., Danchin A., Yokota A.: Was photosynthetic RuBisCO recruited by acquisitive evolution from RuBisCO-like proteins involved in sulfur metabolism? - Res. Microbiol. 156: 611-618, 2005.

Bi Y.F., Che W.G., Gu L.: [Polymorphic characteristics and origin analysis of wild alfalfa population (Medicago sativa L.) in Deqin area.] - Acta Agr. Sin. 15: 306-311, 2007. [In Chinese] doi: 10.11733/j.issn.1007-0435.2007.04.002.

Biswas D.K., Ma B.L., Xu H. et al.: Lutein-mediated photoprotection of photosynthetic machinery in Arabidopsis thaliana exposed to chronic low ultraviolet-B radiation. J. Plant Physiol. 248: 153160, 2020.

Chaves M.M., Flexas J., Pinheiro C.: Photosynthesis under drought and salt stress: Regulation mechanisms from whole plant to cell. - Ann. Bot.-London 103: 551-560, 2009.

D.M., Antunes W.C., Pinheiro D.P. et al.: Tobacco guard cells fix $\mathrm{CO}_{2}$ by both Rubisco and PEPcase while sucrose acts as a substrate during light-induced stomatal opening. - Plant Cell Environ. 38: 2353-2371, 2015.

Das A., Eldakak M., Paudel B. et al.: Leaf proteome analysis reveals prospective drought and heat stress response mechanisms in soybean. - Biomed Res. Int. 2016: 6021047, 2016.

Demmig-Adams B.: Carotenoids and photoprotection in plants: A role for the xanthophyll zeaxanthin. - BBA-Bioenergetics 
1020: 1-24, 1990.

Demmig-Adams B., Adams III W.W.: Photoprotection and other responses of plants to high light stress. - Annu. Rev. Plant Phys. 43: 599-626, 1992.

Dhami N., Drake J.E., Tjoelker M.G. et al.: An extreme heatwave enhanced the xanthophyll de-epoxidation state in leaves of Eucalyptus trees grown in the field. - Physiol. Mol. Biol. Pla. 26: 211-218, 2020.

Eskling M., Arvidsson P.-O., Åkerlund H.-E.: The xanthophyll cycle, its regulation and components. - Physiol. Plantarum 100: 806-816, 1997.

Flexas J., Bota J., Loreto F. et al.: Diffusive and metabolic limitations to photosynthesis under drought and salinity in $\mathrm{C}_{3}$ plants. - Plant Biol. 6: 269-279, 2004.

Flexas J., Medrano H.: Drought-inhibition of photosynthesis in $\mathrm{C}_{3}$ plants: Stomatal and non-stomatal limitations revisited. Ann. Bot.-London 89: 183-189, 2002.

Flexas J., Ribas-Carbó M., Bota J. et al:: Decreased Rubisco activity during water stress is not induced by decreased relative water content but related to conditions of low stomatal conductance and chloroplast $\mathrm{CO}_{2}$ concentration. New Phytol. 172: 73-82, 2006.

Frank H.A., Bautista J.A., Josue J.S., Young A.J.: Mechanism of nonphotochemical quenching in green plants: Energies of the lowest excited singlet states of violaxanthin and zeaxanthin. Biochemistry-US 39: 2831-2837, 2000.

Furumoto T., Izui K., Quinn V. et al.: Phosphorylation of phosphoenolpyruvate carboxylase is not essential for high photosynthetic rates in the $\mathrm{C}_{4}$ species Flaveria bidentis. Plant Physiol. 144: 1936-1945, 2007.

Gallego-Tévar B., Peinado-Torrubia P., Álvarez R. et al.: From physiology to salt marsh management challenges with sea level rise: the case of native Spartina foliosa, invasive S. densiflora and their hybrid. - Conserv. Physiol. 8: coaa053, 2020a.

Gallego-Tévar B., Peinado-Torrubia P., Álvarez R. et al.: Changes to the functional traits of phosphoenolpyruvate carboxylase following hybridization in C-4 halophytes. Physiol. Plantarum 169: 83-98, 2020b.

Gao S., Su P.X., Yan Q.D., Ding S.S.: Canopy and leaf gas exchange of Haloxylon ammodendron under different soil moisture regimes. - Sci. China Life Sci. 53: 718-728, 2010.

García-Mauriño S., Monreal J., Alvarez R. et al.: Characterization of salt stress-enhanced phosphoenolpyruvate carboxylase kinase activity in leaves of Sorghum vulgare: independence from osmotic stress, involvement of ion toxicity and significance of dark phosphorylation. - Planta 216: 648-655, 2003.

Gerganova M., Popova A.V., Stanoeva D., Velitchkova M.: Tomato plants acclimate better to elevated temperature and high light than to treatment with each factor separately. Plant Physiol. Bioch. 104: 234-241, 2016.

Gilmore A.M.: Xanthophyll cycle-dependent nonphotochemical quenching in photosystem II: Mechanistic insights gained from Arabidopsis thaliana L. mutants that lack violaxanthin deepoxidase activity and/or lutein. - Photosynth. Res. 67: 89-101, 2001.

Gilmore A.M., Yamamoto H.Y.: Linear models relating xanthophylls and lumen acidity to non-photochemical fluorescence quenching. Evidence that antheraxanthin explains zeaxanthinindependent quenching. - Photosynth. Res. 35: 67-78, 1993.

Gong D.H., Wang G.Z., Si W.T. et al.: Effects of salt stress on photosynthetic pigments and activity of ribulose-1,5bisphosphate carboxylase/oxygenase in Kalidium foliatum. Russ. J. Plant Physl+ 65: 98-103, 2018.

Greer D.H., Weedon M.M.: Modelling photosynthetic responses to temperature of grapevine (Vitis vinifera cv. Semillon) leaves on vines grown in a hot climate. - Plant Cell Environ. 35: 1050-1064, 2012.

Guo D.P., Guo Y.P., Zhao J.P. et al.: Photosynthetic rate and chlorophyll fluorescence in leaves of stem mustard (Brassica juncea var. tsatsai) after turnip mosaic virus infection. - Plant Sci. 168: 57-63, 2005.

Hao L., Wang Y., Zhang J. et al.: Coronatine enhances drought tolerance via improving antioxidative capacity to maintaining higher photosynthetic performance in soybean. - Plant Sci. 210: 1-9, 2013.

Hassanzadeh M., Ebadi A., Panahyan-e-Kivi M. et al.: Evaluation of drought stress on relative water content and chlorophyll content of sesame (Sesamum indicum L.) genotypes at early flowering stage. - Res. J. Environ. Sci. 3: 345-350, 2009.

Hinojosa L., Sanad M.N.M.E., Jarvis D.E. et al.: Impact of heat and drought stress on peroxisome proliferation in quinoa. Plant J. 99: 1144-1158, 2019.

Honoki R., Ono S., Oikawa A. et al.: Significance of accumulation of the alarmone (p)ppGpp in chloroplasts for controlling photosynthesis and metabolite balance during nitrogen starvation in Arabidopsis. - Photosynth. Res. 135: 299-308, 2018.

IPCC 2014: Climate Change 2014: Synthesis Report. Contribution of Working Groups I, II and III to the Fifth Assessment Report of the Intergovernmental Panel on Climate Change. Pp. 151. IPCC, Geneva 2014.

Jiang Y.W., Huang B.R.: Physiological responses to heat stress alone or in combination with drought: A comparison between tall fescue and perennial ryegrass. - HortScience 36: 682-686, 2001.

Johnson M.P., Davison P.A., Ruban A.V., Horton P.: The xanthophyll cycle pool size controls the kinetics of nonphotochemical quenching in Arabidopsis thaliana. - FEBS Lett. 582: 262-266, 2008.

Lawlor D.W., Cornic G.: Photosynthetic carbon assimilation and associated metabolism in relation to water deficits in higher plants. - Plant Cell Environ. 25: 275-294, 2002.

Lawlor D.W., Tezara W.: Causes of decreased photosynthetic rate and metabolic capacity in water-deficient leaf cells: A critical evaluation of mechanisms and integration of processes. Ann. Bot.-London 103: 561-579, 2009.

León-Sánchez L., Nicolás E., Prieto I. et al: Altered leaf elemental composition with climate change is linked to reductions in photosynthesis, growth and survival in a semiarid shrubland. - J. Ecol. 108: 47-60, 2020.

LiH.S.: [Determination of the activity of ribulose 1,5-bisphosphate carboxylase.] - In: Li H.S. (ed.): [The Experimental Principle and Technology in the Plant Physiology and Biochemistry.] Pp. 138-142. Higher Education Press, Beijing 2000. [In Chinese]

Li R., Wang Y.J., He C.G. et al.: [Effect of drought and heat stress on morphology and photosynthetic pigment contents of Medicago sativa.] - Grassl. T. 35: 37-43, 2015. [In Chinese] doi: 10.13817/j.cnki.cyycp.2015.01.007.

Liang G., Bu J., Zhang S. et al.: Effects of drought stress on the photosynthetic physiological parameters of Populus $\times$ euramericana 'Neva'. - J. Forestry Res. 30: 409-416, 2019.

Liguori N., Croce R., Marrink S.J., Thallmair S.: Molecular dynamics simulations in photosynthesis. - Photosynth. Res. 144: 273-295, 2020.

Liu C., Liu Y., Guo K. et al.: Effect of drought on pigments, osmotic adjustment and antioxidant enzymes in six woody plant species in karst habitats of southwestern China. Environ. Exp. Bot. 71: 174-183, 2011.

Liu J., Guo Y.Y., Bai Y.W. et al.: Effects of drought stress on the 
photosynthesis in maize. - Russ. J. Plant Physl+ 65: 849-856, 2018.

Lu Q., Lu C., Zhang J., Kuang T.: Photosynthesis and chlorophyll $a$ fluorescence during flag leaf senescence of field-grown wheat plants. - J. Plant Physiol. 159: 1173-1178, 2002.

Lundqvist T., Schneider G.: Crystal structure of activated ribulose-1,5-bisphosphate carboxylase complexed with its substrate, ribulose-1,5-bisphosphate. - J. Biol. Chem. 266: 12604-12611, 1991.

Ma X.L., Bi Y.F.: [Isozyme studies on polyphenol oxidase and superoxide dismutase of wide and escaped alfalfa germplasm resources in Yunnan.] - Acta Agr. Sin. 19: 509-515, 2011. [In Chinese] doi: 10.11733/j.issn.1007-0435.2011.03.026.

Majumdar S., Ghosh S., Glick B.R., Dumbroff E.B.: Activities of chlorophyllase, phosphoenolpyruvate carboxylase and ribulose-1,5-bisphosphate carboxylase in the primary leaves of soybean during senescence and drought. - Physiol. Plantarum 81: 473-480, 1991.

Morales F., Ancín M., Fakhet D. et al.: Photosynthetic metabolism under stressful growth conditions as a bases for crop breeding and yield improvement. - Plants-Basel 9: 88, 2020.

Mu L., He C.G., Jiang H. et al.: [The effects of drought and heat stress on the photosynthetic characteristics of alfalfa.] - Acta Agr. Sin. 22: 550-555, 2014. [In Chinese] doi: $10.11733 /$ j. issn.1007-0435.2014.03.017.

Najar R., Aydi S., Sassi-Aydi S. et al.: Effect of salt stress on photosynthesis and chlorophyll fluorescence in Medicago truncatula. - Plant Biosyst. 153: 88-97, 2019.

Panković D., Sakač Z., Kevrešan S., Plesničar M.: Acclimation to long-term water deficit in the leaves of two sunflower hybrids: photosynthesis, electron transport and carbon metabolism. J. Exp. Bot. 50: 128-138, 1999.

Parry M.A.J., Andralojc P.J., Khan S. et al.: Rubisco activity: Effects of drought stress. - Ann. Bot.-London 89: 833-839, 2002.

Pfündel E., Bilger W.: Regulation and possible function of the violaxanthin cycle. - Photosynth. Res. 42: 89-109, 1994.

Rai R., Agrawal M., Agrawal S.B.: Effects of ambient $\mathrm{O}_{3}$ on wheat during reproductive development: Gas exchange, photosynthetic pigments, chlorophyll fluorescence, and carbohydrates. - Photosynthetica 49: 285-294, 2011.

Redondo-Gómez S., Mateos-Naranjo E., Davy A.J. et al.: Growth and photosynthetic responses to salinity of the saltmarsh shrub Atriplex portulacoides. - Ann. Bot.-London 100: 555-563, 2007.

Rizhsky L., Liang H.J., Mittler R.: The combined effect of drought stress and heat shock on gene expression in tobacco. Plant Physiol. 130: 1143-1151, 2002.

Rizhsky L., Liang H.J., Mittler R.: When defense pathways collide. The response of Arabidopsis to a combination of drought and heat stress. - Plant Physiol. 134: 1683-1696, 2004.

Sánchez-Rodríguez J., Pérez P., Martínez-Carrasco R.: Photosynthesis, carbohydrate levels and chlorophyll fluorescenceestimated intercellular $\mathrm{CO}_{2}$ in water stressed Casuarina equisetifolia Forst. \& Forst. - Plant Cell Environ. 22: 867873, 1999.

Sattar A., Sher A., Ijaz M. et al.: Terminal drought and heat stress alter physiological and biochemical attributes in flag leaf of bread wheat. - PLoS ONE 15: e232974, 2020.

Sehgal A., Sita K., Kumar J. et al.: Effects of drought, heat and their interaction on the growth, yield and photosynthetic function of lentil (Lens culinaris Medikus) genotypes varying in heat and drought sensitivity. - Front. Plant Sci. 8: 1776,
2017.

Tang L., Cai H., Zhai H. et al.: Overexpression of Glycine soja WRKY20 enhances both drought and salt tolerance in transgenic alfalfa (Medicago sativa L.). - Plant Cell Tiss. Org. 118: 77-86, 2014.

Tewari A.K., Tripathy B.C.: Temperature-stress-induced impairment of chlorophyll biosynthetic reactions in cucumber and wheat. - Plant Physiol. 117: 851-858, 1998.

Tzortzakis N., Chrysargyris A., Aziz A.: Adaptive response of a native Mediterranean grapevine cultivar upon short-term exposure to drought and heat stress in the context of climate change. - Agronomy 10: 249, 2020.

Vieira E.A., Silva M.D.G., Moro C.F., Laura V.A.: Physiological and biochemical changes attenuate the effects of drought on the Cerrado species Vatairea macrocarpa (Benth.) Ducke. Plant Physiol. Bioch. 115: 472-483, 2017.

Wang Y.J., Jiang H., Bi Y.F., Zhao F.: [Photosynthesis physiological response to dry-hot environment in alfalfa.] J. Yunnan Agr. Univ. 26: 90-193, 2011. [In Chinese] doi: 10.3969/j.issn.1004-390X(n).2011.02.008.

Wassie M., Zhang W., Zhang Q. et al.: Effect of heat stress on growth and physiological traits of alfalfa (Medicago sativa L.) and a comprehensive evaluation for heat tolerance. Agronomy 9: 597, 2019.

Wei C.L., Jiang C.J., Tao H.Z.: [Analysis of the xanthophyll leaves of tea plant by high cycle component in fresh chromatography and its performance liquid photoprotection.] - J. Tea Sci. 24: 60-64, 2004. [In Chinese] doi: 10.3969/j.issn.1000369X.2004.01.012.

Weng X.Y., Xu H.X., Jiang D.A.: Characteristics of gas exchange, chlorophyll fluorescence and expression of key enzymes in photosynthesis during leaf senescence in rice plants. J. Integr. Plant Biol. 47: 560-566, 2005.

Xu C., He C.G., Duan X.H. et al.: [Determining the content of xanthophyll cycle components in alfalfa leaves by HPLC.] J. Yunnan Agr. Univ. 34: 820-825, 2019. [In Chinese] doi: 10.12101/j.issn.1004-390X(n).201904083.

You L., Zhang Y., Li L. et al:: Involvement of abscisic acid, $\mathrm{ABI} 5$, and PPC2 in plant acclimation to low $\mathrm{CO}_{2}$. - J. Exp. Bot. 71: 4093-4108, 2020.

Yu M.H., Mao Z.C., Ye S.H.: [Determination of chloroplast pigment content (spectrophotometric method).] - In: Ye S.H. (ed.): [Plant Physiology and Biochemistry Eperiment Course.] Pp. 116-119. Yunnan Science and Technology Press, Yunnan 2004. [In Chinese]

Zhang Q., Liu X., Zhang Z. et al.: Melatonin improved waterlogging tolerance in alfalfa (Medicago sativa) by reprogramming polyamine and ethylene metabolism. - Front. Plant Sci. 10: 44, 2019.

Zhang Z., Wang Y., Chang L. et al.: MsZEP, a novel zeaxanthin epoxidase gene from alfalfa (Medicago sativa), confers drought and salt tolerance in transgenic tobacco. - Plant Cell Rep. 35: 439-453, 2016.

Zhao Y., Guo A., Wang Y., Hua J.: Evolution of PEPC gene family in Gossypium reveals functional diversification and GhPEPC genes responding to abiotic stresses. - Gene 698: 61-71, 2019.

Zhao Y.L., Xiong H., Bi Y.F. et al.: [Effect of drought and heat stress on leaf stomata size in alfalfa.] - J. Yunnan Agr. Univ. 28: 336-339, 2013. [In Chinese] doi: 10.3969/j.issn.1004390X(n).2013.03.009.

Zhou R., Yu X., Ottosen C.-O. et al.: Drought stress had a predominant effect over heat stress on three tomato cultivars subjected to combined stress. - BMC Plant Biol. 17: 24, 2017.

(C) The authors. This is an open access article distributed under the terms of the Creative Commons BY-NC-ND Licence. 